斜方向については下斜方向に比して上斜方向がより正し く反応され，上方向がより優位である・(4) したがって二 次元空間に和ける方向の分化は次のような順序で行われ る.上, 下, 左右, 上斜, 下斜, 左右についてはまだ明 瞭な区別老することがでさない。

この結果怯，成人の視力の方向性についての小保内の 結論と符合し (10) さらに小保内・新井によって示され た電気ショックによる知覚機構の回復経路の傾向 $(6,11)$ と注涪同じで女る。

\section{交献}

1) Stern, W. Über verlagerte Raumformen. Z. angewand. Psychol., 1909, 2, 478-

2) Oetjen, F. Die Bedeutung der Orientierung des Lesestoffes für das Lesen und der Orientierung von sinnlosen Formen für das Wiedererkennen derselben. Z. Psychol., 1915, 71, $321-355$.

3) Gellerman, L. W. Form discrimination in chimpanzee and two-year old children:

I. Form (triangularity) per se. J. genet. Psychol., 42, 3-
II. Form versus background. J. genet. Psychol., 42, 28-.

4) Volkelt, H. Fortshritte der experimentellen Kinderpsychologie. IX.Kong. f. exper. Psy. chol., 1926, 80-135.

Primitive Komplexqualitäten in Kinderzeichnungen. VIII. Kong. f. exper. Psychol., 1924, 204-208.

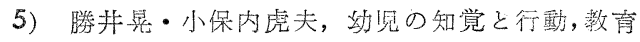
心理学, 第 3 集, 18 - .

6) 新井康祐 - 小保内虎夫, 知覚の層構造, 心研, 1957, 28, 94-106.

7) 小林さ之見童の臨画に打ける变容現象の一 研究, 心研, 1937, 12, 375-392。

8) 生沢雅夫 空間的配置図形の記憶の発達, 人文 研究 (大阪市立大学) , 1956,7,264一

9) 大野晋一転位された図形の認知に関する発 達心理学的研究, 同上, $251-845$.

10) 小保内虎夫視空間構造の実跧的研究, 心研 $1930,5,805-845$.

11) 小保内虎夫 視知覚, 東京 中山書店 昭30 (1955), 81
-1958.6.10. 受稿—

\title{
図形知覚における発達曲線の比較的考察 1
}

一一発達曲線に和よ添す図形と知覚条件の差異*-

一静岡大学勝并滉炡-

\section{I 実験目的}

1. 幼览に対ずる知覚実験は，その実験方法が根本的 に問題である. 本来, 精神構造とのるのの未分化な幼児 を対象として，知覚反応そのもの总純粋に抽出すること は，きわめて困難なことである。しか子従来多くとられ て来た, 描画法等の間接的方法では, 多くの媒介要因が 入り, 又学習的方法も問題解決のための知的要因が強く 㗢く結果となり易い。

そこで本実験では, 実験操作をできうる限り簡単に し, 又 verbal-response を避けて, 手先操作てより知 覚反応が得られるよう工夫した。

2. 前記の点に留意しつつ, 幼児の図形知覚に和汸る 正確度の発達曲線を吟味しょうとした。すなわち, 明膫

* Curves of Development in Figure Perception. 1.

** Akira Katsui (Shizuoka University).
な方向性を示す一群の図形と, 一定の角度差をもった， 角度図形和よび円弧図形群とを標準刺激とし，同一平面 上にランダムに呈示された比較図形群の中から, 同一図 形を選択ささる、次には, 標準図形を取り去り, 再認法 によって選択させる。

これらの選択に执ける正確度をみると, 図形の種類, 選択方法の差等により，その絶対值は異なるが，発達的 な正確率は，きわめて近似したカーヴを得ることができ る。すなわ方, 図形の二次元的方向, 角度, 凯よび弧の 大小を手がかりとした，同一図形選択に和ける正確度の

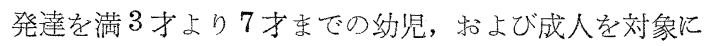
検討しょうとした。

3. とくに, それらの発達曲線を, 成人の平均得点に 対する各年令平均得点の相対的位置求めて描くことに よって, 図形や知覚条件による差学分析するとともに, 幼览が成人の知覚水準に到達するまでの発達過程を考察 
し，更には，各種の図形に共通した，一般的発澾曲線を 追及しょうと思う。

今回以その一部として, 図形 3 種類, 知覚条件 2 種類 に打子る，条件差と発達曲線を中心に報告する。

\section{II 実験方法}

実默合 1.Fig. 1 の標準図形を，1つずつランダムに。 Fig. 2 の上部刺激呈示空に，5秒間呈示する. 各図形ご とに呈示後， 5 秒経過した時，下部空に 8 方向を示す同 一困形群を呈示し，標集図形を再憘させる，再認時間は 10 秒以内, 試行 1 回.

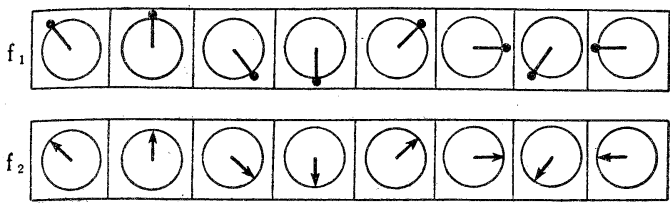

Fig. 1. Exp. 1, Exp. 2 標準図形

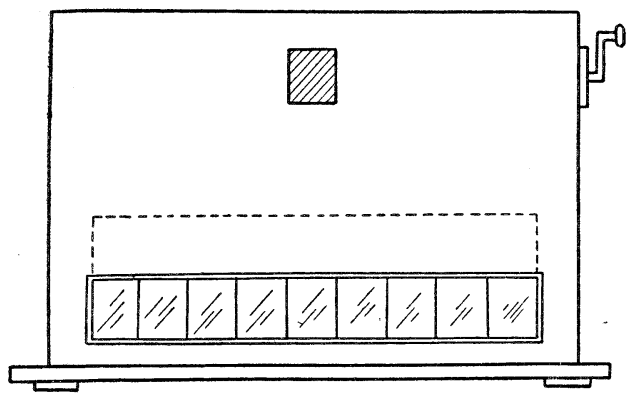

Fig. 2. 刺激呈示板

被験者は炊の構成による。

\begin{tabular}{|c|c|c|c|c|c|c|}
\hline C.A. & $\begin{array}{l}3: 0 \\
{ }^{3}: 11\end{array}$ & $\begin{array}{l}4: 0 \\
i^{4}: 11\end{array}$ & $\begin{array}{l}5: 0 \\
\vdots \\
5: 11\end{array}$ & $\begin{array}{l}6: 0 \\
i^{6}: 11\end{array}$ & $\begin{array}{l}7: 0 \\
\vdots \\
7: 11\end{array}$ & $\begin{array}{l}\text { Adult } \\
\text { (大学生) }\end{array}$ \\
\hline$n$ & 30 & 30 & 30 & 30 & 30 & 30 \\
\hline
\end{tabular}

実験 2. Fig. 1 と同一図形を Exp. 1 と同一方法で 呈示し，標準図形を取り去らないで，その木ま呈示し， 下部空に呈示された比較図形群中より，同一四形を選択 させる。

被験者構成は，Exp. 1 と同一，但乙被験者は別グル $-フ ゚$.

实験 3. Fig. 3 の標準図形を，1つずつランダムに

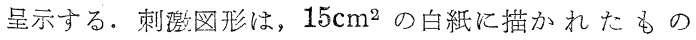
を, 瞬間露出器にて 5 秒間呈示.

これを取り去った後，比較刺激りストを呈示し再認さ せる。比皎刺激りストは, 標準図形を中心として $\pm 2^{\circ}$ ずつの角度差（円弧図形のば岕いは，弧の切れ目に対す る内角)をるって变化する標準図形より大きい図形10個, 小さい図形10個，計 21 個の図形をランダムに白紙 $(30 \mathrm{~cm}$ $\times 40 \mathrm{~cm}$ ) に描いたもの.

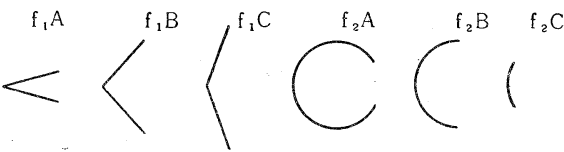

Fig. 3. Exp. 3, Exp. 4 標準図形

被験者は次の横成による。

( 1 カ月末満は切り捨て)

\begin{tabular}{|c|c|c|c|c|c|c|}
\hline C.A. & $\begin{array}{l}4: 0 \\
4: 11\end{array}$ & $\begin{array}{l}5: 0 \\
5: 11\end{array}$ & $\begin{array}{l}6: 0 \\
6: 11\end{array}$ & $\begin{array}{l}7: 0 \\
7 \sim 11\end{array}$ & $\begin{array}{l}8: 0 \\
8 ! 11\end{array}$ & $\begin{array}{c}\text { Adult } \\
\text { (大学生) }\end{array}$ \\
\hline & 35 & 40 & 50 & 50 & 50 & 50 \\
\hline
\end{tabular}

実験 4. Fig. 3 の標準図形そ Exp. 3 と同一方法で 呈示し，その屯ま取り去らないで，比較刺激を呈示し， 同一戝形を選択させる。

被験者構成は Exp. 3 と同じ，但し被験者は別グルー プ.

実験 5. Fig. 3 の標準図形を呈示後, 取り去って, 同大の白紙に描画再生させる。再生は直後，24時間後，

1 週間後の 3 時期. 円弧図形に拈いては，白紙に，5す い破線で完全円周をプリントしてある。角度扣よび弧 の長さを测定し, $\pm 2^{\circ}$ 以内の deviation で再生された ものを，正磪再生とする.

被験者構成は Exp. 3 と同じ。但し被験者は別グルー プ.

以上の諸実験は, いずれも, 昭和 29 年 10 月より, 昭和 32年 3 月にかけて, 下記の静岡市内, 幼稚園, 保育園, 大学附属小学校, 大学実験室に祘いて, 実施された。

幼稚園……静大附属幼稚園, 市立安東幼稚園, 平塚市 双葉幼稚園

保育園……静岡市千代田保育園, 平塚市平塚保育園 小学校……静大附属小学校, 市立安東小学校 大 学……静岡大学教育学部心理専攻学生

\section{III 実 験 結果}

1. Exp. 1， Exp. 2. 方向図形に和㚈正正確度.

8 万向, 2 種類, 計16個の標準刺激図形に対する正確 選択頻数を，再認選択 (Exp. 1)，同時選 択 (Exp. 2) 別に示すと Table 1 のようになる.

Table 1 Exp. 1.

\begin{tabular}{|c|c|c|c|c|c|c|}
\hline C.A. & $\begin{array}{c}3.0 \sim 11 \\
3.11\end{array}$ & $\begin{array}{c}4.0 \sim \\
4.11\end{array}$ & $\begin{array}{c}5.0 \sim \\
5.11\end{array}$ & $\frac{6.0 \sim}{6.11}$ & $\frac{7.0 \sim}{7.11}$ & Adult \\
\hline Total & 73 & 224 & 298 & 338 & 374 & 448 \\
\hline$M$ & 2.4 & 7.5 & 9.9 & 11.3 & 12.7 & 14.9 \\
\hline$\%$ & 15.2 & 46.8 & 62.8 & 70.5 & 77.9 & 93.3 \\
\hline
\end{tabular}

Exp. 2.

\begin{tabular}{c|c|c|c|c|c|r}
\hline C.A. & $3.0 \sim$ & $4.0 \sim$ & $5.0 \sim$ & $6.0 \sim$ & $7.0 \sim$ & Adult \\
\hline Total & 14.11 & 4.11 & 5.11 & 6.11 & 7.11 & \\
$M$ & 4.9 & 243 & 315 & 372 & 402 & - \\
$\%$ & 30.6 & 50.6 & 10.5 & 12.4 & 13.4 & - \\
$\%$
\end{tabular}

C. A。は曆年令, $M$ は各個人の16図形に和预る平均正確得点. \% は Total を全選択数で割ったもの. 
Exp. 2の同時選択に和いては, 予備実験の結果成人(大 学生)のばあい100\%で女ったため, 本実験は省略した。

次にこの結果について, 分散分析を行い（F検定）各 年令群間, 拉よび，選択条件間の差をみると，Table 2 のようになる。

Table 2 Analysis of variance

\begin{tabular}{l|r|r|r|c}
\hline Source & d.f. & M.S. & F & significant \\
\hline 選択条件 & 1 & 98.5 & 15.3 & $* *$ \\
年 令 & 4 & 817.3 & 127.7 & $* *$ \\
交互作用 & $1 \times 4$ & 8.97 & 1.4 & \\
謂 差 & 290 & 6.6 & & \\
\hline Total & 299 & 931.3 & &
\end{tabular}

すなわち，同時選択と再認による選択との間には，正 確度の間に有意差が認められ, 各年令間に㸚いても, 全

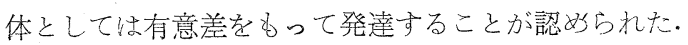
この点は, Fig. 4 に示す, 正確度（\%）の曲線によって も朝らかであらう。

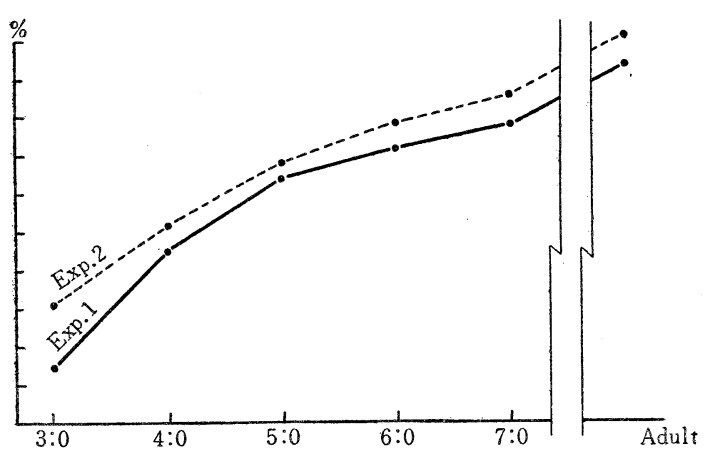

Fig. 4 .

2. Exp. 3, Exp. 4. Hebb の用いた角度図形, 円弧 図形に沶ける, 同時選択と再認による正確選択頻数と正 確度（\%）をみるとTable 3 のようになる・(この場合 は, 実験の都合により, 各, 標準図形に和ける正確な選 択齿数 (人員) の総計をるって，正確得点とした。した がって $M$ は各個人の平均得点ではなく, 各図形の平均 得点である.\%は Exp. 1, 2 と同様, 正確な選択の合 計を総選択数で割ったもの.)

このばあいる, 両条件, 年令群間の差をみると Table 4 のごとくなり，発達曲線をみると Fig. 5 のようになる.

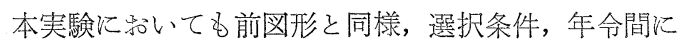
全体として有意差が認められ，とくに，選択条件による 差は非常に大きい。
Table 3 Exp. 3.

\begin{tabular}{c|r|r|r|r|r|r}
\hline C.A. & $\begin{array}{r}4: 0 \sim \\
4: 11\end{array}$ & $5: 0 \sim 11$ & $6: 0 \sim 11$ & $7: 0 \sim 11$ & $8: 0 \sim$ & $8: 11$ \\
\hline Total & 24 & 40 & 57 & 94 & 120 & 133 \\
$M$ & 4.0 & 6.6 & 9.5 & 15.7 & 20.0 & 27.8 \\
$\%$ & 11.4 & 16.5 & 19.0 & 31.4 & 40.0 & 44.3
\end{tabular}

Exp. 4

\begin{tabular}{c|c|c|c|c|c|c}
\hline Total & 42 & 132 & 165 & 206 & 218 & 246 \\
$M$ & 7.0 & 18.3 & 26.5 & 34.4 & 36.4 & 41.0 \\
$\%$ & 20 & 46 & 54 & 69 & 73 & 82
\end{tabular}

Table 4 Analysis of variance

\begin{tabular}{|c|c|c|c|c|}
\hline Source & d. $f$. & M. S. & $F$ & significant \\
\hline 選択条件 & 1 & 15254.2 & 292.7 & $* *$ \\
\hline 年令 & 5 & 4238.6 & 81.3 & $* *$ \\
\hline 交互作用 & $1 \times 5$ & 332.0 & 6.3 & \\
\hline 誤差 & 71 & 52.1 & & \\
\hline Total & 82 & 19876.9 & & \\
\hline
\end{tabular}

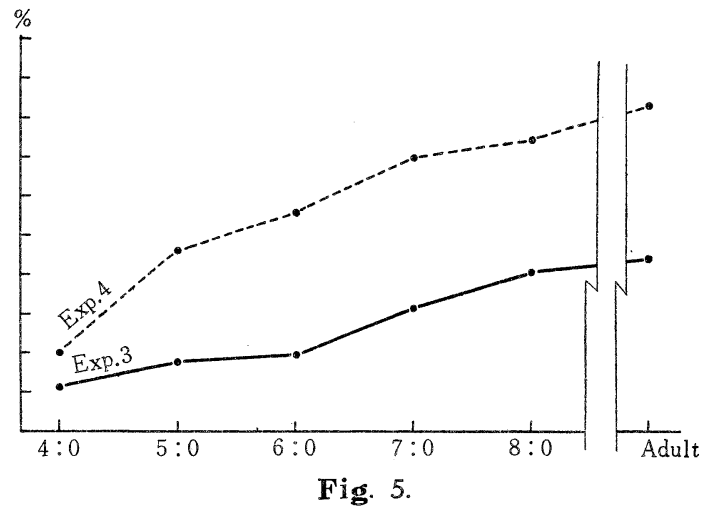

3. Exp. 5.この淁いは，描画再生という，手先の 運動的要因が大きく働くので,正確度の意味は, 前実験群 とはやや異質的なるのとなるが比較対照のためその結果 そみる. (正確反応は前迹の基準により決定し, 本数值は 直後再生のみの結果による.)この正確再生率と発達曲線 をみると Table 5 和よび Fig. 6 のようになる。（この 場合の正確得点の合計と平均は Exp.3，4 と同じ算出 法による.)

Table 5 Exp. 5

\begin{tabular}{c|l|l|l|l|r|r|r}
\hline C. A. & $4: 0 \sim 11$ & $5: 0 \sim 11$ & $6: 0 \sim$ & $7: 0 \sim$ & $8: 0 \sim$ & Adult \\
\hline Total & 2 & 46 & 77 & 95 & 115 & 167 \\
$M$ & 0.3 & 7.7 & 15.6 & 16.6 & 19.1 & 27.8 \\
$\%$ & 0.95 & 19.1 & 28.6 & 31.6 & 38.3 & 55.6
\end{tabular}




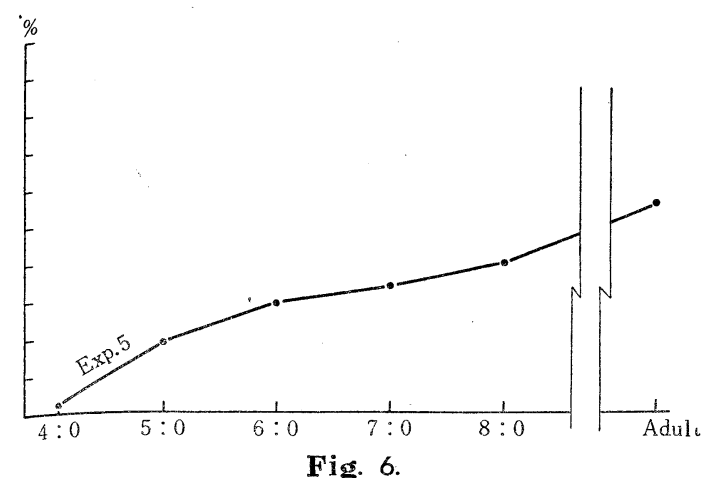

このばあいは，手先の技能的要因が入るので予想通り正 確度は低く，上昇率子緩慢であり成人に特いてさ点 55.6 \%であった。しかし， Exp. 3 の再認のばあいの正確度 ときわめて近似であることは注目される・ただしこれ は, 正確再生として認めうる誤差の許容量によって变化 するので一義的には論じえない。

\section{IV 考、察}

1. 比較図形群の中から, 標準図形を選択するばあ い, 同一平面上に拈いて, 標準図形を呈示したまま選択 させたばあいの方が，再認によって選択させたばあいよ り, その正確度に搞いて, 各図形とも, 有意差をもっ て，高率であることは当初より予想されたことであっ た。これは, 再認のばあい, その媒介となる図形の記憶 が幼巟にとって極めて困難であるとからる当然である う・とくにこれは，選択の手がかりとなる図形の形態， 大小，方向等の性質によって大きく規定される：このこ とは Exp. 1，2のような明蹽な方向性を示す弁別容易 な図形群に执いては, 正確度子高く, 選択条件による差 も比較的すくないが, Exp. 3，4のような, わずかの角 度差, 円弧差によって弁別選択するばあい, 正確度は前 者より低く，選択条件による差も大きいことからも明ら かである.とくに Exp. 3 のような, 極めて近似な図形 群の中から, 再認するという課題が, 幼児にとっていか に困難であるかは, その正確度が極めて低く, 又成人に

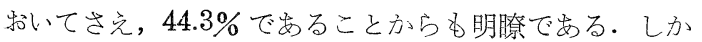
もこのばあい, 幼児の知覚反応が成人の反応と異なり, いわゆる多くの “でたらめ反応”を含んでいることにつ いても，十分吟味されね杖ならな。—この問題につ いては後述—

2. 前述のごとく, 図形や選択条件の相違によって, そ の正碓度の絶対值は異なるが，相対的には年令段階子追 って，有意差をもって上昇を示している。これは，5実 験比讨る正確度の年令別百分率を, 角度変換值（角度 $=\arcsin \sqrt{\%})(1)$ に上って全体的に分散分析した結果 (年令差 $F=46.7 * *$ ，汜択条件差 $F=80.2 * *$ ) 加歹明ら
かである。

そこで，この発達曲線炎相互に比較すると，成人の正 確水準に対する各年令段階の相対的発達曲線は, 岁る程 度，近似したカーヴを示すことがわかる．今，各実験に 和计る, 成人の平均得点に対する, 各年命の平均得点の 相対度数（\%) 在求めその曲線を描くと Fig. 7 の上 になる。

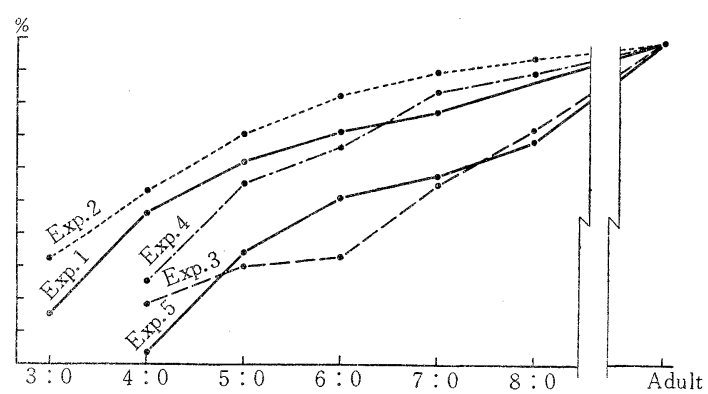

Fig. 7 .

これをみると「方向図形」の正確度 (Exp. 1, Exp. 2) ほ, 同時, 再認之电に, 一番高く, 加早小発達速度を 示し，3才で15〜30\%であのたるのが，4才で50\%前 後，5才で60〜 70\%，6才で70〜80\%，7才で 80 ９0\% と比較的スムーズなカーヴを示している。

これに対し「角度峙よび円弧図形」の将あいは, やや 不規則で，同時選択のばあい(Exp. 4) は，4才で $25 \%$ で方向図形の $1 / 2$ の正確度しか得られず，岕は Exp

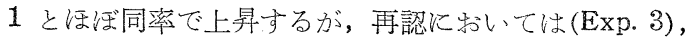
前群と比較して，上昇率が低く，4才で $20 \% ， 5$ 才で $30 \% ， 6 才 て ゙ 32 \% ， 7 ， 8$ 才にいたって，よ5やく50〜 60\%にいたる・これは, 前述のように, 図形の弁別困難 性と記憶の要因が入るためと思われるが，この Exp. 3 の正確度が，再生による(Exp. 5) 正確度と, 泟汸近 似であることは，注目すべき問題を残している。

3.2 2 述べたように，それぞれの曲線は，図形，条 件の違いによって, 正確度の絶対值は異なるが, 成人水 準に対する，相対的発澾率は，極めて大まかに友たと き，ほぼ近似の様相を呈している．今描画再生という， 異質の実験結果だけは除外して, 他の知覚選択による 4 つの場合の正答率を，それぞれ年令別に平均して(これ は, Fig. 7 に示された，成人に対する相対度数（\%）の 平均ではなく，個々の実験の正答数から通算平均したも の), 成人に対与る相対曲線（\%）学求めて描くと，Fig. 8 のようになる.(このばあい, 成人水準を 100 として,

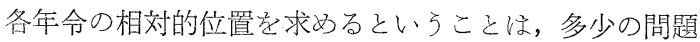
があると思われるが, 本研究の目的で㐫る, 成人の知覚 水準に到達するまでの発達的過程を久るにあたって，問 題の相違により，成人の平均正答数が異なるために，成 


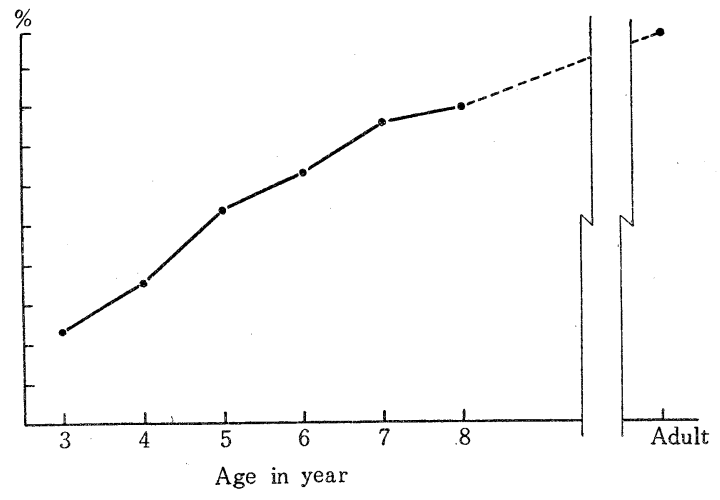

Fig. 8.

人を100としたばあいの各年令段階の成就率を％で求 め，それを平均したるのである。したがって大まかな， 全体的傾向は把握できるが，個々の曲線の性格は，相殺 されてしまう憾はまぬがれない）

さて，この曲線からごく一般的な傾向をいうならば， 満 1，2才に和いては，実験不能のため，その正確度は 不明で女るが，3才台に执いて，汪湾 $30 \%$ 前後の成人水 準に対する成就率が得られ，3才ょり6才までに急速な 発達を示し，7，8才台に执いて，やや緩慢となり，成 人水準に対してほ滦 70〜80\%の成就率に達する.その後 は，きわわて潮進的に成人水準に到達するということが できよう、したがって, 図形知覚に执いて, 図形の方向 や, 角度の大小に対する知覚に関する限り, その発達上 升期は 3 才前後から，7，8才までが，もっとも著し く, 8 才前後に执いて, 注添成人に近い正確水準に到達 すると,いいうるであらう・

知覚の発達は, 他の感覚系統の発達と同様 Scamon, R.E.による神経型 Neural-type に近いとすれば，思考 や記憶の発達より早く $6 ， 7$ 才でほぼ成人の $90 \%$ 前後に 到達することになるが，これを Thurstone, L.とAckerson が Stanford-Binet Test にもとづき, 絶対尺

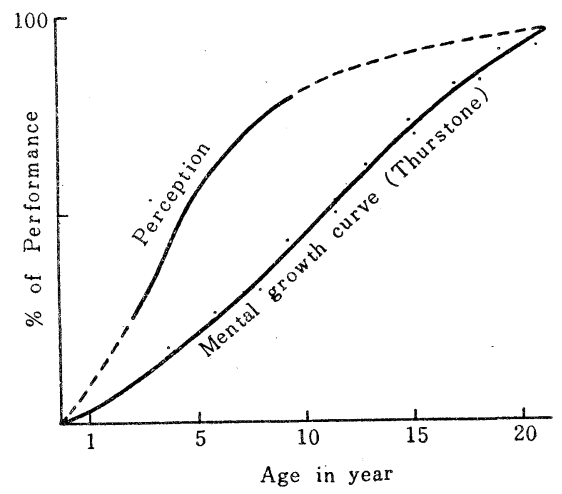

Fig. 9.
度法により，心理機能の一般的成長曲線を計量化してい るが (2)，これと本実験の平均曲線とをごく大まかに対 比してみると Fig. 9 のようになる。

これをみると, 知覚のばあいは, 知能曲線よりはるか に早く, 成人水準に到達し, そのカーヴの性格はやや $S$ 字型に近いことがわかる。

4. 勿論, 本実験結果より得られた発達曲線には, 多 くの問題点がある・市ず第1亿本実験は，きわめて特殊 な3 群の図形に幽ける知賞の場合であって, 図形の形 態，大小，色調的配合等を变化させることによって，そ の選択に特ける正確度は変化し, 発達曲線も異なった型 を示す事は明らかである。しかも，再認のばあいは，記 憶要因が大きく働くので，その点も十分考慮せ齐ばなら ない。したがって，本実験結果をもって，ただらに図形 知覚一般の発達曲線を示するのと考光得ないことは勿論 である。本研究に和いては，女る特定の条件下に和ける 図形知覚の成人水準に対する，相対的傾向を極めて大亦 かに把握するとともに，図形や知覚条件による差を吟味 せんとしたものである。

次にこの種の実験の根本問題としての反応の信頼度に ついて,特に 3 才前後に和いて正確度が低い,ということ は, 幼児の知覚反応そのものが, その水準程度に拈いて 未発達であるというよりは, 幻児の実験課題に対する反 応そのものがでたらめである事, 否それ以前に, 彼等が 問題の意味そのものを，すなわち instruction そのもの. をどのように理解しているかということが問題である. このようなばあい起る「でたらめ反応」とでる称せられ， る反応は，できうる限り除外することは勿論であるが， 実験操作のコントロール, 試行回数の反復による確率的 方法等により, 方法的にも工夫されるとともに, 結果の 解釈に和いて，十分考察せね齐ならない。しかし，この 年令段階にある幼児から, 知覚反応々のものを純粋に抽 出しょうとすることは, きわめて困難である以上, 実験 方法が根本的間題として残されるわけである。

したがって，本実験結果に执いてる，この点を十分考 慮せね孙ならないと思う。

最後に, このような方法上の問題を十分検討しつつ, 3 才以下, 打よび7才以降の発達過程を吟味するととも に，各種の形態的特質をもった図形について実験しそ～ れらを基にして, 図形知覚の一般的な成長曲線を求め, 出来うれば数理的解析を加えたいと思う。これには前述 の Thurstone, L.L. の成長曲線の仮説 (3) や, 直線, 扣よび曲線回帰に関する公式等 (4) が, 何等かの手がか りになるのではないかと思われる。

\section{文献}

1) スネデカー, 烟村又好他訳 統計的方法, 下, 東 京 岩波書店 昭25 (1950), pp. 438-440。 
2) Thurstone, L.L., \& Ackerson, L. The mental growth curve for the Binet Tests. J. educ. Psychol., 1929, 20, 569-583.

3) Thurstone, L.L. The absolute zero in intelligence mesurement. Psychol. Rev., 1928, 35,175-197.

4) スネデカー，畑村又好他訳 統計的方法, 上,
$\S 13$, 東京 岩波書店 昭 25 (1950).

5) 腾井晃 - 小保内虎夫 図形の再生と再認に打け る誤りの特質，心研，1956，27，352-361.

6)勝井晃・眓形知覚に括ける発達曲線の比較的考 察 No. 3, 静岡大学教育学部研究報告, No. 7 . 1955.

- 1958. 6. 18. 受稿 